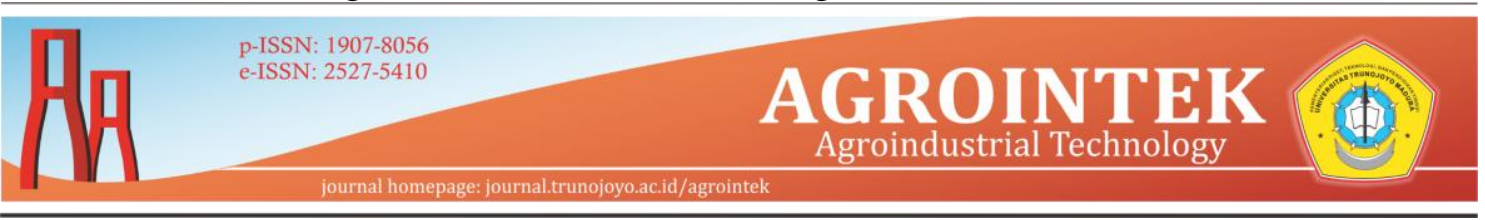

\title{
FAKTOR PENGHAMBAT PENERAPAN GOOD MANUFACTURING PRACTICES PADA PROSES PENGENDALIAN KUALITAS BANDREK DI CV. X
}

\author{
Sarah Jasmine Latief ${ }^{1 \dagger}$, Lucyana Trimo ${ }^{2}$ \\ ${ }^{1}$ Mahasiswa Program Studi Agribisnis, Universitas Padjadjaran, Bandung, Indonesia \\ ${ }^{2}$ Dosen Program Studi Agribisnis, Universitas Padjadjaran, Bandung, Indonesia
}

Article history

Diterima: 23 Mei 2019

Diperbaiki:10 Juli 2019

Disetujui:12 Juli 2019

$\underline{\text { Keyword }}$

$G M P$,

Fishbone,

Quality,

Inhibiting Factor

\begin{abstract}
Along with the increasing production of food and beverage industry in Indonesia, people today insist on the hygienic food product. CV.X is an Industry that produces instant drinks. However, $C V . X$ has not implemented Good Manufacturing Practices on the quality control of its products. There are employees who have not complied with the regulations while working and the machine has been damaged several times, so it inhibits the production process. As a result, product defects are resulting in as much as 5\% of total production. The design used in this research is qualitative with case study techniques. The analysis techniques used in this research is descriptive analysis techniques with a tool named fishbone diagram. The result showed that $72 \%$ of GMP aspects had been fulfilled, but $28 \%$ had not been, so the implementation of GMP was hampered. According to the fishbone diagram result, there are four inhibiting factors that had been identified.
\end{abstract}

(C) hak cipta dilindungi undang-undang

\footnotetext{
$\dagger$ Penulis korespondensi

Email: sarahjasmine00@gmail.com

DOI: http://dx.doi.org/10.21107/agrointek.v13i2.5331
} 


\section{PENDAHULUAN}

Seiring dengan semakin berkembangnya industri makanan dan minuman di Indonesia, masyarakat akan semakin selektif dalam memilih produk pangan untuk dikonsumsi. Konsumen pangan semakin jeli dalam memilih produk, seperti menghindari makanan dengan bahan-bahan tertentu yang dapat membahayakan tubuh ataupun berdasarkan sensitifitas dan alergi, hingga kepercayaan pribadi. Dikutip dari Nielsen's New Global Health and Ingredient-Sentiment Survey, 64\% dari responden mengatakan bahwa mereka bersedia membayar lebih untuk makanan dan minuman yang bebas dari bahanbahan yang membahayakan atau tidak diinginkan. CEO Tetrapak Brian Kennell dalam Huffington Post menyebutkan bahwa salah satu ciri-ciri produk yang menjadi incaran konsumen ialah produk dengan berlabel bersih (clean foods) (Lubis, 2016). Oleh karena itu, produsen industri harus terus meningkatkan kualitas produk pangan dengan menyusun strategi dalam pengendalian kualitas produknya. "Kualitas produk adalah keseluruhan ciri serta dari suatu produk atau pelayanan pada kemampuan untuk memuaskan kebutuhan yang dinyatakan/tersirat" (Kotler, 2005). "Kualitas produk merupakan salah satu faktor yang paling diandalkan seorang pemasar dalam memasarkan produk" (Kotler \& Armstrong, 2003).

Konsumen pangan tentunya menginginkan produk pangan dengan kualitas tinggi, terlebih lagi pada produk pangan yang nantinya akan dikonsumsi agar produk tersebut tidak membahayakan kesehatan konsumen. Konsumen pangan pada saat ini sudah mulai menyadari bahwa mutu dan keamanan pangan tidak hanya dijamin oleh hasil uji laboratorium saja. Konsumen pangan memiliki keyakinan bahwa dengan pemakaian bahan baku yang baik, bahan ditangani dengan baik, diolah dan didistribusikan dengan baik maka menghasilkan produk akhir yang baik. (Daulay, 2000). Untuk menghasilkan produk pangan yang layak dikonsumsi, maka pemerintah telah mensyaratkan produsen untuk menerapkan Good Manufacturing Practice (GMP) sebagai salah satu cara untuk meningkatkan kualitas produk yang dihasilkan serta dapat memberikan kepercayaan kepada konsumen bahwa produk yang ditawarkan produsen aman dan layak dikonsumsi (Rudiyanto, 2016). "GMP adalah suatu pedoman cara memproduksi makanan dengan tujuan agar produsen memenuhi persyaratanpersyaratan yang telah ditentukan untuk menghasilkan produk makanan bermutu sesuai dengan tuntutan konsumen" (Rini, Katili, \& Ummi, 2015). GMP diimplementasikan pada saat proses awal produksi (penerimaan bahan baku) hingga penyimpanan produk jadi. "GMP harus diterapkan oleh industri produk pangan sebagai upaya preventif agar pangan yang siap dikonsumsi tersebut bersifat aman, layak, dan berkualitas" (Triesty \& Ririh, 2011).

CV. X merupakan salah satu industri kecil menengah yang sukses dalam penjualan minuman instant. Dipilihnya CV. $\mathrm{X}$ sebagai lokasi penelitian dikarenakan oleh beberapa alasan. Pertama, Produk-produk yang dihasilkan CV. X populer di daerah Jawa Barat. Kedua, CV. X telah dinobatkan sebagai IKM berprestasi oleh Pemerintah Provinsi Jawa Barat. Ketiga, CV. X memiliki ciri khas yang unik di mana produksi produk menggunakan mesin yang dirancang sendiri dikarekan latar belakang dari CV. $\mathrm{X}$ ialah teknik. Bahkan, mesin rancangan CV. X dipakai oleh beberapa perusahaan baik swasta maupun negri karena dinilai bagus dalam pengolahan bahan-bahan. Produk yang akan diteliti pada penelitian ini adalah Bandrek Original. Dipilihnya Bandrek original sebagai objek penelitian 
dikarenakan produk tersebut merupakan produk yang memiliki penjualan yang lebih banyak daripada produk lain yang ditawarkan CV. X. Produk tersebut juga diakui CV.X sebagai produk yang paling banyak diminati masyarakat.

Bandrek original diproduksi menggunakan bahan baku alami yang tergolong mudah rusak sehingga butuh penanganan yang baik agar menghasilkan produk sesuai standar perusahaan. Menurut informan kunci, banyak karyawan yang melanggar peraturan seperti makan dan minum saat bekerja dan lalai dalam mengawasi mesin yang beroperasi. Informan juga mengatakan bahwa mesin yang digunakan pernah mengalami kerusakan sehingga pernah menghambat proses produksi. Selain itu, beberapa kali terdapat adanya cacat produk pada saat produksi yang berjumlah kurang lebih 5\% dari total keseluruhan. Perlu diketahui bahwa CV. X juga belum menerapkan konsep GMP pada proses produksinya. Padahal, Kementerian Perindustrian mengatakan bahwa penerapan food safety tidak membedakan skala usaha kecil, menengah atau besar yang artinya harus diterapkan untuk semua skala usaha. Oleh karena itu, penulis ingin meneliti faktor penghambat apa saja yang terdapat dalam menerapkan GMP pada proses pengendalian kualitas bandrek original pada CV. X. Penelitian ini bertujuan untuk dapat mengetahui faktor-faktor yang menyebabkan apa saja yang menghambat penerapan GMP pada produk bandrek original dan memberikan solusi agar dapat menerapkan GMP.

\section{METODE}

Objek pada penelitian ini adalah faktor penghambat yang ada dalam menerapkan Good Manufacturing Practices (GMP) pada produk bandrek original di CV. X. Metode penelitian yang digunakan ialah kualitatif dengan teknik penelitian studi kasus. Penelitian kualitatif digunakan untuk meneliti suatu kondisi objek yang alamiah di mana peneliti merupakan instrumen kunci, teknik pengumpulan data dilakukan secara triangulasi, serta analisis data bersifat kualitatif (Sugiyono, 2018). Informan yang dipilih dalam memberikan informasi pada penelitian ini adalah Humas dari CV. $\mathrm{X}$, kepala produksi, kepala bahan baku, kepala penyimpanan dan karyawan yang bekerja di tempat produksi.

Untuk mengetahui faktor penghambat apa saja yang ada dalam menerapkan GMP pada pengendalian kualitas produk bandrek original di CV. X , terdapat tiga langkah, yaitu:

1) Membandingkan aspek GMP dengan keadaan yang ada pada proses produksi sehingga dapat diidentifikasi aspek apa saja yang sudah dan belum terpenuhi. Pedoman GMP yang digunakan sebagai acuan ialah berdasarkan Peraturan Menteri Perindustrian RI No 75/MIND/PER/7/2010. Ruang lingkup GMP yang digunakan pada analisis ini adalah ruang lingkup yang terlibat dalam proses pengendalian kualitas mulai dari pemilihan bahan baku hingga produk dikemas. Ruang lingkup GMP yang dimaksud adalah karyawan, mesin dan peralatan, bahan, pengemas, produk akhir, label dan keterangan produk, pengawasan proses dan penyimpanan.

2) Menggunakan diagram fishbone untuk membantu mengidentifikasi, memilah dan memaparkan berbagai penyebab yang mungkin dari suatu masalah atau karakteristik kualitas tertentu (Mustofa, 2014). Faktor yang akan digunakan dalam diagram fishbone adalah faktor yang berkaitan dengan ruang lingkup GMP yang terlibat dalam kegiatan pengendalian kualitas. Berikut adalah tabel pengelompokannya.

3) Membuat solusi dari hasil interpretasi diagram fishbone menggunakan analisis deskriptif. 
Tabel 1. Pengelompokan Faktor dan Ruang Lingkup GMP

\begin{tabular}{ll}
\hline \multicolumn{1}{c}{ Faktor } & Ruang Lingkup GMP \\
\hline Man & Karyawan \\
Machine & Mesin dan peralatan \\
& Bahan \\
& Pengemas \\
& Produk akhir \\
Method & Label dan keterangan produk \\
& Pengawasan proses \\
\hline
\end{tabular}

\section{HASIL DAN PEMBAHASAN}

Berdasarkan hasil dari perbandingan antara pedoman GMP dengan keadaan pada proses pengendalian kualitas bandrek original di CV. X, terdapat 55 aspek sudah terpenuhi, 21 aspek belum terpenuhi dan delapan aspek tidak dilibatkan karena aspek tersebut tidak ditemukan pada $\mathrm{CV}$. $X$. Maka total yang sudah terpenuhi adalah $72 \%$. Artinya, CV. X dalam proses pengendalian kualitas produknya sudah menerapkan sebagian besar aspek GMP. Namun, masih ada aspek yang belum terpenuhi sebanyak $28 \%$ sehingga penerapan GMP masih terhambat.

\section{Pembahasan Ruang Lingkup GMP}

\section{Karyawan}

Di dalam ruang lingkup karyawan, dari sembilan aspek GMP, terdapat tujuh aspek sudah terpenuhi. CV. X sudah menetapkan kompetensi dan tugas yang jelas kepada karyawannya. Saat bekerja, karyawan harus dalam keadaan sehat, mengenakan pakaian kerja yang sudah diberikan, mencuci tangan sebelum kerja, dan tidak memakai aksesoris seperti jam tangan dan hal lainnya yang dapat membahayakan produk. Terdapat satu orang karyawan yang sudah ditetapkan sebagai penanggung jawab pengawasan pengolahan dan telah ditetapkan sebagai kepala produksi. Dua aspek yang belum terpenuhi ialah masih ada karyawan yang makan dan minum saat sedang bekerja. Padahal, hal tersebut dapat membahayakan produk yang dihasilkan. Selain itu, pengunjung yang masuk ke ruang produksi tidak memakai pakaian pelindung.

\section{Mesin dan Peralatan}

Disimpulkan bahwa terdapat 10 aspek sudah terpenuhi dari total 13 aspek pada ruang lingkup mesin dan peralatan. Untuk memproduksi bandrek original, mesin dan peralatan yang digunakan dalam proses produksi sudah sesuai dengan jenis produksi. CV. X membuat sendiri mesin yang digunakan untuk memproduksi bandrek sehingga mesin dan peralatan yang digunakan sesuai dengan tujuan kegunaan dalam proses produksi. Mesin dan peralatan yang bersentuhan dengan bahan baku terbuat dari stainless sehingga memiliki permukaan yang halus, tidak berlubang atau bercelah, tidak mengelupas, tidak menyerap air dan tidak berkarat. Mesin dan peralatan yang kontak langsung dengan bahan baku tidak menimbulkan pencemaran terhadap produk, mudah dilakukan pembersihan, didesinfeksi, dan pemeliharaan. Mesin dan peralatan yang dipakai juga terbuat dari bahan yang tahan lama, tidak beracun dan mudah dipindahkan untuk memudahkan perawatan, pembersihan dan pencucian. Agar proses produksi lancar, mesin dan peralatan sudah diletakkan sesuai dengan urutan proses produksi. Letak mesin dan peralatan mudah dijangkau sehingga dapat dengan mudah diawasi dan dipantau. Terdapat tiga buah aspek GMP yang belum terpenuhi. Mesin dan peralatan hanya dilakukan pemeriksaan, pengawasan dan pemantauan ketika 
sedang dan saat akan dipakai saja. Padahal sudah ada jadwal rutin pemeriksaan mesin namun tidak dilaksanakan dengan baik sehingga mesin pernah rusak saat produksi sedang berlangsung yang menyebabkan produksi terhambat. Selain itu, masih ada mesin yang belum dilengkapi alat pengendali atau pengatur. Sebagian besar mesin masih mengandalkan operator dalam pengoperasiannya. Alat ukur pada mesin seperti alat ukur suhu tidak akurat sehingga menimbulkan kegagalan pada produksi.

\section{Bahan}

Sebanyak sembilan aspek GMP pada ruang lingkup bahan sudah terpenuhi dan satu aspek tidak dilibatkan. Saat akan memulai produksi, bahan yang digunakan sesuai dengan formula dasar yang sudah ditetapkan Standar Nasional Indonesia dan hal ini terbukti dengan adanya hasil uji laboratorium mengenai kandungan yang ada pada produk bandrek original. Bahan yang digunakan tidak merugikan dan membahayakan kesehatan. Sebelum digunakan, bahan baku disortir terlebih dahulu sehingga bahan dipastikan tidak rusak, busuk, mengandung bahan berbahaya dan sesuai standar mutu yang ditetapkan. CV. X menggunakan air yang berasal dari PDAM Kota Cimahi sehingga sudah memenuhi persyaratan air bersih. Air yang digunakan merupakan air yang mengalir dari kran agar terjamin bersih dan tidak tercemar. Tidak ada air yang digunakan berkali-kali.

\section{Pengemas}

Terdapat enam aspek GMP yang sudah terpenuhi dan satu aspek tidak dilibatkan pada ruang lingkup pengemas. Pengemas yang dipakai untuk mengemas bandrek original sudah pernah di uji laboratorium dan terbukti dapat melindungi dan mempertahankan mutu produk terhadap pengaruh luar. Bahan pengemas tidak larut dan tidak melepaskan senyawa-senyawa tertentu yang dapat menimbulkan bahaya pada produk sehingga pengemas dijamin dapat mempertahankan keutuhan dan keaslian produk bandrek original. Pengemas yang digunakan tahan terhadap perlakuan selama pengolahan, pengangkutan dan peredaran selama proses yang telah disebutkan dilakukan dengan baik. Desain dan bahan kemasan yang digunakan sebagai pengemas produk sudah terbukti dapat memberikan perlindungan terhadap produk dalam memperkecil kontaminasi dan memungkinkan pelabelan yang baik.

5. Produk Akhir

Terdapat satu aspek dari total dua aspek GMP yang sudah terpenuhi. Produk akhir sudah dilakukan uji kandungan laboratorium terpecaya sehingga dapat terjamin sudah memenuhi persyaratan yang ditetapkan oleh otoritas kompeten. Aspek yang belum terpenuhi adalah mutu dan keamanan produk akhir hanya dilakukan pemeriksaan secara organoleptik saja, tidak dilakukan pemeriksaan secara kimia, fisika dan mikrobiologi sebelum diedarkan. Menurut informan penelitian, hal tersebut tidak dilakukan karena $\mathrm{CV}$. X belum memiliki laboratorium sendiri sehingga jika uji laboratorium dilakukan setaip sebelum produk akan diedarkan akan memakan waktu yang lama.

6. Label dan Keterangan Produk

Di dalam ruang lingkup label dan keterangan produk terdapat dua aspek GMP dan kedua aspek tersebut sudah terpenuhi. label yang digunakan pada produk bandrek original sudah sesuai dengan ketentuan yang tercantum dalam Peraturan Pemerintah RI Nomor 69 Tahun 1999 di mana label harus berisi informasi mengenai nama produk, daftar bahan yang digunakan, berat bersih, nama dan alamat pihak yang memproduksi, serta tanggal, bulan dan tahun kadaluarsa. Label bandrek original dan produk lainnya yang dihasilkan oleh CV. X memiliki 
kombinasi seperti warna yang berbeda sehingga mudah untuk dibedakan.

\section{Pengawasan Proses}

Sebanyak 22 aspek GMP yang terdapat pada ruang lingkup pengawasan proses. Delapan aspek sudah terpenuhi, sembilan aspek belum terpenuhi dan lima aspek tidak dilibatkan. CV. X dalam pengawasan prosesnya sudah menyusun persyaratan-persyaratan yang berhubungan dengan bahan baku, komposisi pada produk, proses pengolahan produk dan pendistribusian produk sehingga setiap proses memiliki persyaratannya masing-masing. Bahan yang digunakan untuk produksi dipastikan memenuhi persyaratan mutu yang telah ditetapkan dengan melalui proses sortasi. Perusahaan pun memiliki catatan mengenai bahan apa saja yang telah digunakan dalam bentuk catatan harian yang dipegang oleh kepala produksi. Setiap proses produksi diatur agar mencegah masuknya bahan asing ke dalam produk yang diolah. Karyawan yang berada di ruang produksi memakai alat-alat pelindung seperti baju kerja, topi dan sepatu karet karena atribut tersebut adalah ketetntuan atribut yang dipakai karyawan CV. X. Saat bekerja, meja kerja, peralatan dan lantai tempat produksi dipastikan selalu bersih setelah digunakan. Untuk keamanan pada ruang produksi, tidak ada penggunaan bahan gelas atau proselen pada area produksi, area pengemasan dan area penyimpanan. Ratarata bahan yang digunakan adalah bahan plastik atau stainless yang merupakan wadah/alat tara pangan.

Namun, terdapat sembilan aspek yang belum terpenuhi. CV. X sudah mendesain sistem pengawasan yang efektif namun tidak diimplementasikan dengan baik dan belum mengkaji ulang mengapa sistem tersebut belum sepenuhnya diterapkan dengan baik. Hal ini dikarenakan karyawan yang kurang koorperatif. Belum ada petunjuk seperti SOP tertulis di ruang produksi. Selain itu belum ada keterangan seperti SOP untuk setiap satuan pengolahan (satu kali produksi) seperti jenis dan jumlah seluruh bahan yang digunakan dalam satu kali proses produksi. Saat produksi sedang berjalan, waktu dan suhu dalam proses produksi kurang diawasi dengan baik. Masih ada proses produksi yang dilakukan pada saat jam istirahat dan tidak ada karyawan yang mengawasi. Padahal, mesin yang digunakan masih mengandalkan operator dalam pengaturan waktu dan suhu sehingga mengakibatkan gagal produksi. Dapat dikatakan bahwa pengawasan pada tempat produksi tidak mendapat pengawasan dengan baik. Bahan yang digunakan hanya diperiksa secara organoleptik dan fisik saja, tidak diuji secara kimia dan mikrobiologi karena perusahaan belum memiliki laboratorium pribadi. Aspek yang belum terpenuhi lainnya ialah penempatan bahan baku masih bergabung dengan tempat produksi yang dekat dengan drum berisikan bahan yang telah diolah. Seharusnya, bahan baku diletakkan terpisah seperti di gudang bahan baku. Aspek lainnya yang belum terpenuhi ialah karyawan tidak selalu mencuci tangan saat masuk ke dalam ruang produksi. Karyawan berpendapat bahwa jika tidak sedang bekerja maka tidak perlu mencuci tangan. Lampu pada tempat pengolahan, pengemasan dan penyimpan tidak dilindungi dengan bahan yang tidak mudah pecah seperti pelindung lampu.

\section{Penyimpanan}

Terdapat 10 aspek GMP pada ruang lingkup penyimpanan. Tiga aspek sudah terpenuhi yaitu penyimpanan bahan dan produk akhir diberi tanda antara yang sudah dan belum diperiksa serta memenuhi persyaratan dan tidak memenuhi persyaratan. Sebelum masuk ke tempat penyimpanan dilakukan sortasi terlebih dahulu sehingga bahan dan produk akhir yang masuk ke ruang 
penyimpanan pasti sudah diperiksa dan dipastikan sudah memenuhi persyaratan. Metode penyimpanan yang dipakai ialah first-in first out. Sementara sebanyak enam aspek belum terpenuhi dan satu aspek tidak dilibatkan. Aspek yang belum terpenuhi seperti bahan yang digunakan dalam proses pengolahan tidak disimpan terpisah dan masih tergabung di ruang produksi. Seharusnya bahan baku disimpan di ruang terpisah dengan aliran udara terjamin, bebas hama, dan suhu sesuai. Penyimpanan bahan baku tidak ditentukan jumlah tumpukannya sehingga terdapat bahan baku yang mendekati langit-langit. Penyimpanan bahan baku dan produk akhir belum menggunakan sistem kartu. Penyimpanan wadah, pengemas dan label masih tidak sesuai pada tempatnya seperti masih ada wadah yang diletakkan di kantin padahal CV. X memiliki ruang pengemas. Penyimpanan mesin dan peralatan tidak dalam kondisi baik di mana mesin tidak diberi pelindung.

\section{Faktor Penghambat dalam menerapkan GMP}

Setelah mengetahui aspek GMP mana saja yang belum terpenuhi, maka dibuatlah pengelompokan berdasarkan faktor man, machine, material dan method. Kemudian, akan dijabarkan ke tabel brainstorming untuk mengetahui apa saja penyebab kecil dari faktor penghambat. Setelah itu, dilakukan brainstroming untuk menentukan faktor penghambat mana yang paling dominan. Untuk menentukannya, dilakukan brainstroming bersama informan kunci dan mengklarifikasi hasil brainstorming dengan informan pendukung. Brainstorming adalah suatu metode di mana seseorang akan melontarkan suatu masalah ke suatu kelompok diskusi, kemudian para anggota diskusi akan melontarkan apa saja penyebab dari masalah tersebut dan mendiskusikan mengapa masalah tersebut muncul (Roestyah, 2008).

Tabel 2. Hasil Brainstorming untuk Mencari Akar Masalah

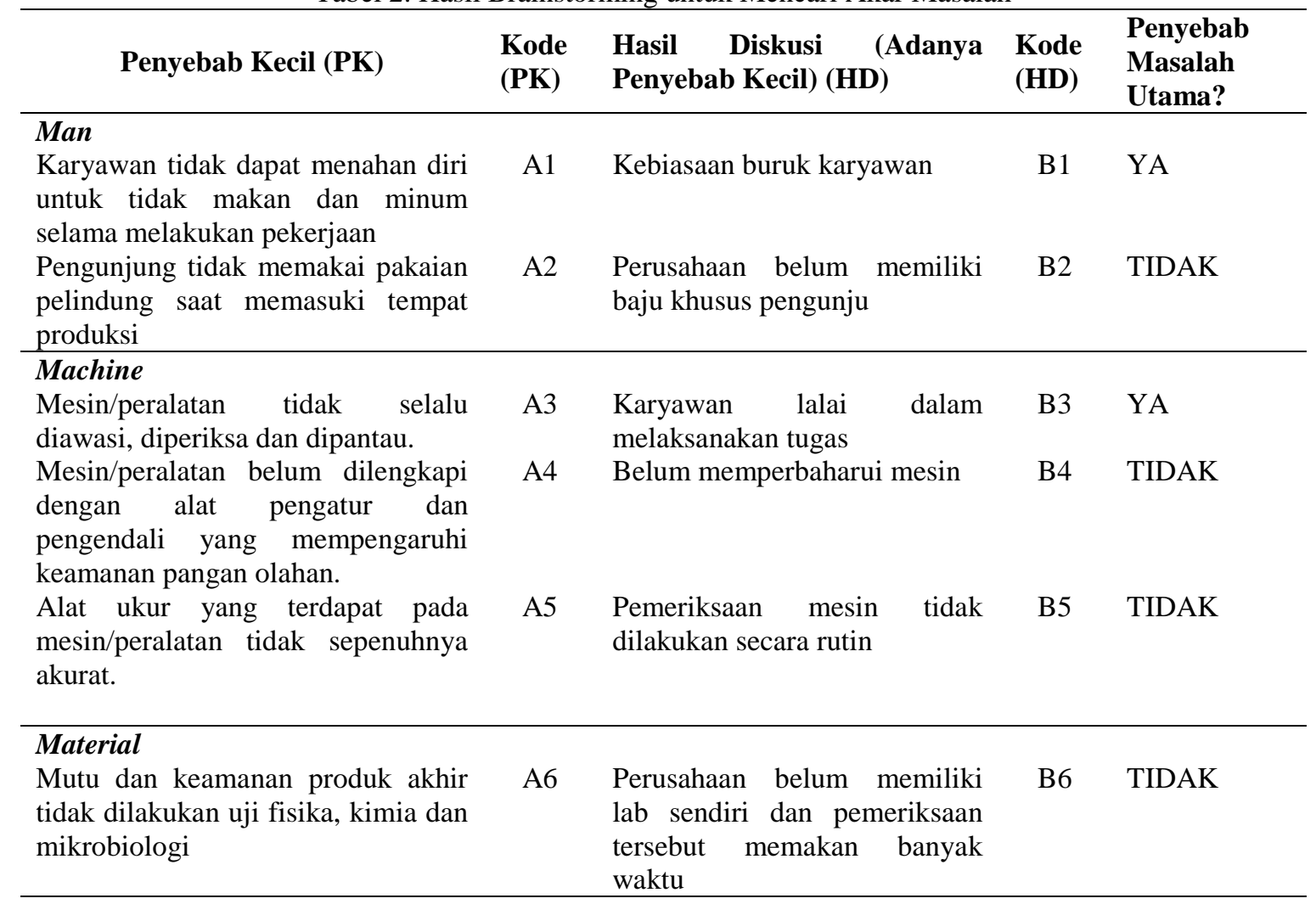




\begin{tabular}{|c|c|c|c|c|}
\hline Penyebab Kecil (PK) & $\begin{array}{l}\text { Kode } \\
(\text { PK) }\end{array}$ & $\begin{array}{l}\text { Hasil Diskusi (Adanya } \\
\text { Penyebab Kecil) (HD) }\end{array}$ & $\begin{array}{l}\text { Kode } \\
\text { (HD) }\end{array}$ & $\begin{array}{l}\text { Penyebab } \\
\text { Masalah } \\
\text { Utama? }\end{array}$ \\
\hline $\begin{array}{l}\text { Tidak ada petunjuk pada setiap } \\
\text { satuan pengolahan } \\
\text { produksi) }\end{array}$ & A7 & $\begin{array}{l}\text { Informasi hanya dipegang oleh } \\
\text { kepala produksi dan belum ada } \\
\text { papan tulis untuk menulis } \\
\text { informasi }\end{array}$ & B7 & TIDAK \\
\hline $\begin{array}{l}\text { Produk belum dilengkapi petunjuk } \\
\text { saat proses produksi. }\end{array}$ & A8 & $\begin{array}{l}\text { Karyawan sudah dianggap tau } \\
\text { dan tidak ada papan tulis untuk } \\
\text { menulis petunjuk. }\end{array}$ & B8 & TIDAK \\
\hline $\begin{array}{l}\text { Belum mengimplementasikan, } \\
\text { memantau dan mengkaji ulang } \\
\text { sistem pengawasan yang efektif. }\end{array}$ & A9 & $\begin{array}{l}\text { Karyawan tidak koorperatif } \\
\text { dalam menerapkan sistem } \\
\text { pengawasan dan belum adanya } \\
\text { solusi yang efektif }\end{array}$ & B9 & TIDAK \\
\hline $\begin{array}{ll}\text { Waktu dan suhu dalam proses } \\
\text { produksi } & \text { tidak } \\
\text { pengawasan dengan baik }\end{array}$ & A10 & $\begin{array}{l}\text { Karyawan lalai dalam } \\
\text { melaksanakan pengawasan }\end{array}$ & B10 & YA \\
\hline $\begin{array}{l}\text { Bahan yang akan digunakan tidak } \\
\text { diuji secara kimia dan mikrobiologi }\end{array}$ & A11 & $\begin{array}{l}\text { Uji dengan inderawi saja sudah } \\
\text { cukup }\end{array}$ & B11 & TIDAK \\
\hline $\begin{array}{l}\text { Bahan tidak disimpan terpisah dari } \\
\text { bahan yang telah diolah }\end{array}$ & A12 & $\begin{array}{l}\text { Gudang bahan baku terlalu } \\
\text { sempit sehingga bahan baku } \\
\text { diletakkan di ruang produksi } \\
\text { yang berdekatan dengan bahan } \\
\text { yang telah diolaH }\end{array}$ & B12 & TIDAK \\
\hline $\begin{array}{l}\text { Tempat produksi tidak selalu } \\
\text { mendapatkan pengawasan dengan } \\
\text { baik }\end{array}$ & A13 & $\begin{array}{l}\text { Karyawan yang ditunjuk } \\
\text { memiliki tanggung jawab yang } \\
\text { lain sehingga tidak dapat } \\
\text { memberikan pengawasan } \\
\text { dengan baik pada ruang } \\
\text { produksi }\end{array}$ & B13 & TIDAK \\
\hline $\begin{array}{l}\text { Karyawan tidak mencuci tangan } \\
\text { sebelum masuk ke tempat produksi }\end{array}$ & A14 & $\begin{array}{l}\text { Karyawan beranggapan bahwa } \\
\text { jika tidak kerja dan menyentuh } \\
\text { produk maka tidak perlu } \\
\text { mencuci tangan }\end{array}$ & B14 & TIDAK \\
\hline $\begin{array}{l}\text { Lampu di tempat pengolahan, } \\
\text { pengemas dan penyimpanan belum } \\
\text { dilindungi dengan bahan yang tidak } \\
\text { mudah pecah }\end{array}$ & A15 & $\begin{array}{l}\text { Belum ada rencana untuk } \\
\text { pemasangan pelindung lampu }\end{array}$ & B15 & TIDAK \\
\hline $\begin{array}{l}\text { Bahan yang digunakan pada proses } \\
\text { pengolahan tidak disimpan di } \\
\text { ruangan terpisah }\end{array}$ & A16 & $\begin{array}{l}\text { Gudang bahan baku terlalu } \\
\text { sempit }\end{array}$ & B16 & YA \\
\hline $\begin{array}{l}\text { Penyimpanan bahan baku dekat } \\
\text { dengan langit-langit atap }\end{array}$ & A17 & $\begin{array}{l}\text { Maksimal untuk penumpukan } \\
\text { bahan baku belum diatur }\end{array}$ & B17 & TIDAK \\
\hline $\begin{array}{l}\text { Penyimpanan bahan dan produk } \\
\text { akhir belum memakai sistem kartu }\end{array}$ & A18 & $\begin{array}{l}\text { Belum adanya penyusunan } \\
\text { rencana untuk pembuatan } \\
\text { sistem kartu }\end{array}$ & B18 & TIDAK \\
\hline $\begin{array}{l}\text { Wadah atau pengemas diletakkan } \\
\text { tidak pada tempatnya }\end{array}$ & A19 & $\begin{array}{l}\text { Gudang kemasan sudah tidak } \\
\text { muat }\end{array}$ & B19 & TIDAK \\
\hline $\begin{array}{l}\text { Penyimpanan mesin/peralatan yang } \\
\text { sudah dibersihkan namun belum } \\
\text { digunakan tidak dalam kondisi baik }\end{array}$ & A20 & $\begin{array}{l}\text { Karyawan malas menutup } \\
\text { mesin dengan penutup mesin }\end{array}$ & B20 & TIDAK \\
\hline
\end{tabular}

Setelah mengetahui apa saja menerapkan GMP, penyebab tersebut penyebab dominan atau akar masalah diberi tanda pada diagram fishbone untuk yang menjadi penghambat dalam 
menandakan bahwa masalah yang dilingkari merupakan penyebab dominan.

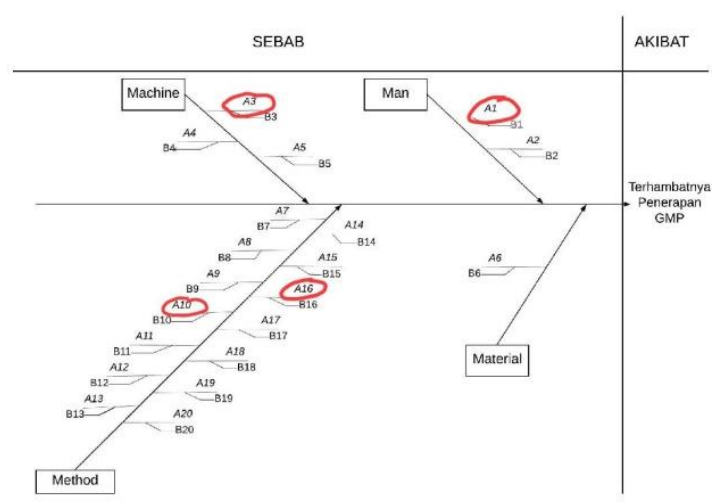

Gambar 1. Hasil Diagram Fishbone

Berdasarkan hasil dari diagram fishbone dan brainstorming untuk mencari akar masalah, faktor penghambat dalam menerapkan GMP pada produksi bandrek original adalah:

1) Karyawan masih tidak dapat menahan diri untuk tidak makan dan minum selama melakukan pekerjaan (A1)

2) Mesin/peralatan tidak selalu diawasi, diperiksa dan dipantau (A3)

3) Waktu dan suhu dalam proses produksi tidak mendapat pengawasan dengan baik (A10)

4) Bahan yang digunakan pada proses pengolahan tidak disimpan di ruangan terpisah (A16)

Ke empat penyebab masalah di atas merupakan masalah yang muncul berkalikali dan disimpulkan bahwa ke empat penyebab masalah tersebut merupakan faktor penyebab dominan terhambatnya penerapan GMP.

\section{Solusi yang Dapat Diterapkan}

Setelah mengetahui apa saja faktor penghambat dalam menerapkan GMP pada produksi bandrek original, maka dibentuk solusi yang dapat diterapkan untuk dapat menerapkan GMP, yaitu:

1) Memberikan pelatihan bulanan dan briefing harian kepada karyawan mengenai pentingnya penerapan GMP, food safety dan hal penting lainnya pada saat produksi bandrek original (Wardhanu \& Anhar, 2016). Diharapkan karyawan akan dapat menerapkan dan tidak melanggar aturan yang ada selama proses produksi berlangsung.

2) Mengadakan penilaian terhadap karyawan setiap dua minggu sekali. Untuk karyawan yang dapat menjalankan pekerjaan dengan baik akan mendapatkan tunjangan hadiah. Menurut (Tohardi, 2002), hadiah atau penghargaan adalah "suatu ganjaran yang diberikan untuk memotivasi karyawan sehingga produktivitasnya tinggi”. Dapat disimpulkan bahwa pemberian tunjangan diberikan agar dapat memotivasi karyawan untuk terus bekerja lebih baik dengan mematuhi aturan yang berlaku.

3) Mengubah letak bahan baku agar tidak tergabung di ruang produksi dengan memanfaatkan ruangan yang kosong yang berada di lantai dua perusahaan. Lancarnya suatu proses produksi dapat dilihat dari beberapa faktor, salah satunya desain tata letak fasilitas-fasilitas perusahaan. Desain tata letak yang baik dapat membuat aktivitas produksi menjadi lebih efektif dan efisien sehingga berdampak pula pada kualitas produk yang lebih baik (Purnomo, Rusdianto, \& Hamdani, 2012). Berikut adalah saran skema tata letak yang sudah peneliti simpulkan yang merupakan hasil diskusi dengan Informan Kunci. 


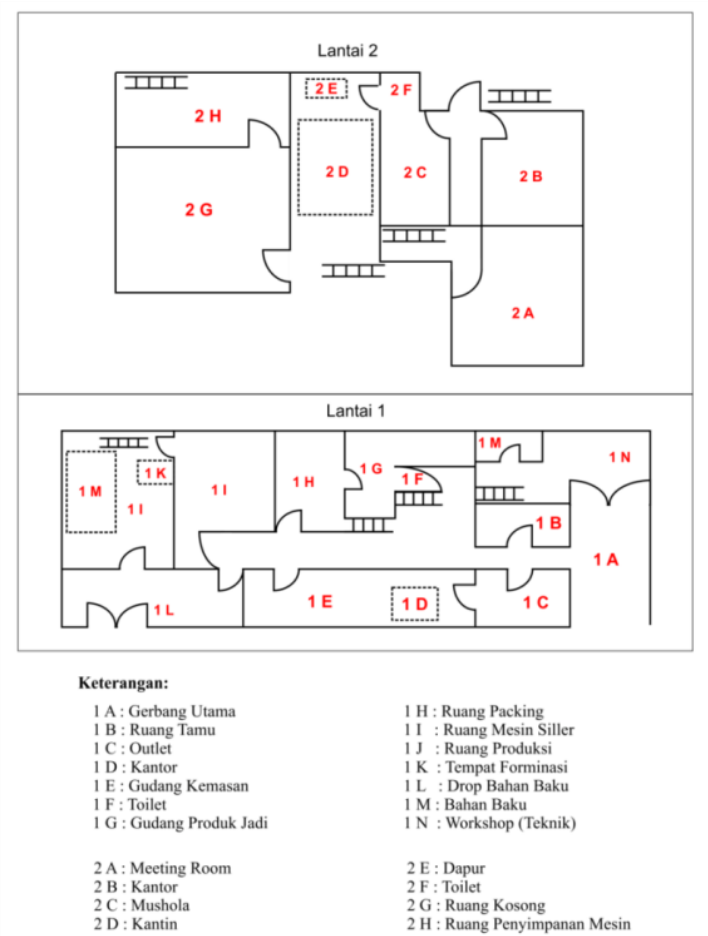

Gambar 2. Lay Out Pabrik CV. X

Terlihat pada gambar di atas bahwa ruang produksi $(1 \mathrm{~J})$ dan tempat formulasi (1K) bergabung dengan tempat penyimpanan bahan baku (1M). Menurut aspek GMP, bahan baku harus dipisah tempat penyimpanannya dan tidak boleh bergabung dengan tempat produksi. Terdapat ruang kosong (2G) di lantai dua pabrik CV. $\mathrm{X}$ sehingga dapat dimanfaatkan agar penyimpanan bahan baku tidak tergabung di ruang produksi.

Setelah adanya perubahan lay out, terdapat perubahan menguntungkan lainnya seperti:

1) Gudang bahan baku sudah lebih luas sehingga dapat menampung semua bahan baku. gudang bahan baku yang lama akan dipakai sebagai ruangan untuk menyimpan mesin.

2) Ruang produksi, drum hasil olahan dan tempat formulasi sudah tidak menyatu lagi dengan bahan baku yang diletakkan pada 1I.

3) Ruang mesin filler dan packing dipindahkan ke lantai dua $(2 \mathrm{H}$ dan 2G pada Gambar 21). Untuk memudahkan pengangkutan bahan yang sudah diolah ke ruang mesin filler, drum yang berisikan serbuk bandrek dapat diangkut menggunakan lift khusus barang yang berada di ruangan produksi yang terhubung langsung ke ruangan mesin filler. Setelah produk selesai dikemas di ruang packing $(2 \mathrm{G})$, produk yang sudah jadi diangkut menggunakan lift yang berada di ruang packing dan langsung terhubung ke ruangan produk jadi $(1 \mathrm{H})$.

4) Kantor yang terdapat pada lantai satu (1D) yang menyatu dengan gudang kemasan (1E), dipindahkan ke ruang produk jadi yang lama (1G pada Gambar 21) Pemindahan kantor tersebut dapat menampung kemasan atau wadah lebih banyak sehingga kemasan dan wadah yang terletak pada kantin dapat diletakkan pada gudang kemasan.

5) Pemindahan ruang mesin filler dan ruang packing $(2 \mathrm{G}$ dan $2 \mathrm{H}$ pada Gambar 21) berdekatan dengan kantin (2D) dapat mengurangi kebiasaan karyawan untuk membawa makanan dan minuman di ruangan kerja. 


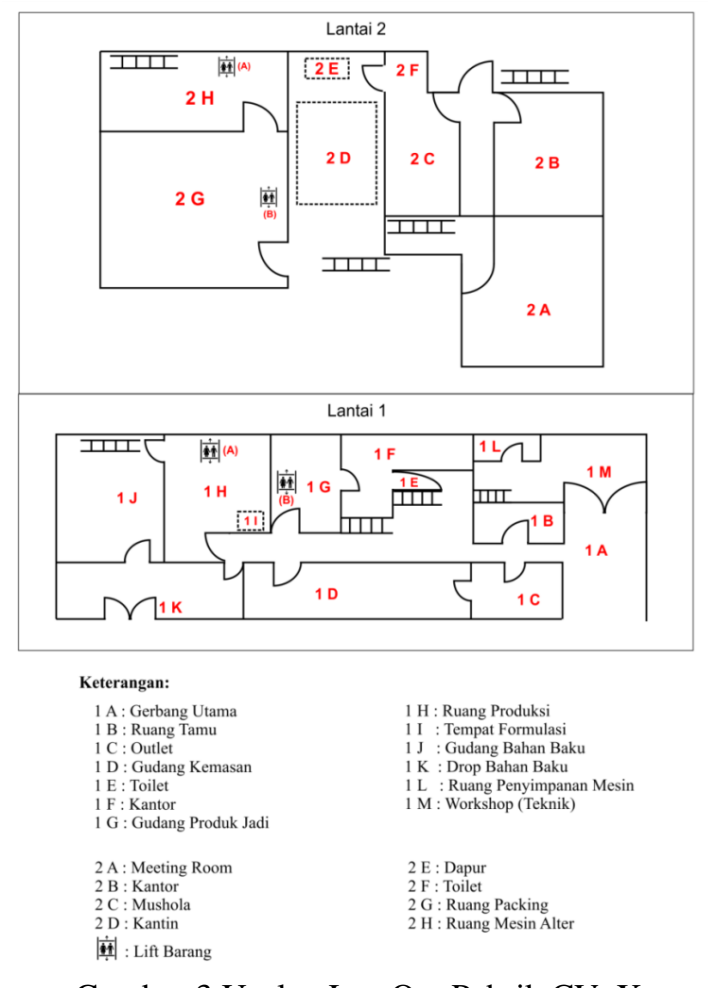

Gambar 3 Usulan Lay Out Pabrik CV. X

Membuat papan informasi yang berisi karyawan mana yang sedang bertugas dalam memeriksa mesin pada hari itu sehingga terlihat siapa yang sedang bertanggung jawab pada hari itu. Karyawan yang sedang bertugas diharuskan untuk mengisi papan informasi dengan membuat checklist pada papan agar terlihat bahwa bagian tersebut sudah diperiksa. Tabel pemeriksaan mesin dibuat untuk dapat memastikan bahwa mesin-mesin pada ruang produksi aman untuk dioperasikan. Jika ada kendala dalam pengoperasian maka dapat langsung teridentifikasi dan dapat ditangani dengan cepat. Karyawan yang ditugaskan untuk memeriksa mesin sudah ditetapkan sebelumnya melalui pertemuan dengan pimpinan sehingga sudah jelas karyawan mana yang bertanggung jawab.

Pemeriksaan Mesin

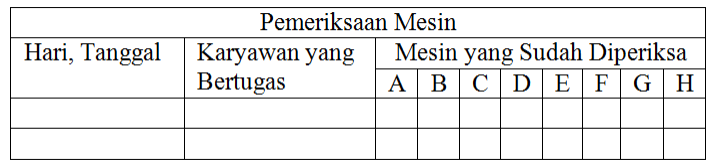

Gambar 4. Contoh Tabel Pemeriksaan Mesin
Karyawan yang ditugaskan dalam memeriksa mesin juga harus dapat memastikan bahwa mesin dioperasikan pada saat jam kerja saja. Jika pada jam istirahat, mesin wajib diberhentikan.

Karyawan yang ditugaskan untuk memeriksa mesin juga memastikan bahwa jika ada mesin yang beroperasi harus ada karyawan yang bertanggung jawab dalam pemantauan pada waktu operasi dan suhu mesin. Ini dilakukan agar mesin tidak terlalu lama beroperasi dari yang seharusnya dan suhu tetap pada standar yang ditetapkan agar tidak terjadi gagal produksi.

\section{KESIMPULAN}

\section{Kesimpulan}

Kesimpulan yang dapat didapat dari hasil penelitian ini adalah sebanyak $72 \%$ aspek GMP sudah diterapkan oleh CV. X dalam memproduksi bandrek original. Namun, sebanyak $28 \%$ belum terpenuhi sehingga penerapan GMP terhambat. Hasil dari diagram fishbone mengatakan bahwa faktor penghambat dalam menerapkan GMP pada produksi bandrek original adalah (1) karyawan tidak dapat menahan diri untuk tidak makan dan minum selama melakukan pekerjaan, (2) mesin/peralatan tidak selalu diawasi, diperiksa dan dipantau, (3) waktu dan suhu dalam proses produksi tidak mendapat pengawasan dengan baik dan (4) bahan yang digunakan pada proses pengolahan tidak disimpan di ruangan terpisah. Solusi yang dapat dilakukan untuk dapat menerapkan GMP adalah (1) memberikan pelatihan bulanan dan briefing harian kepada karyawan mengenai pentingnya penerapan GMP, (2) mengadakan penilaian terhadap karyawan setiap dua minggu sekali, (3) memisahkan letak bahan baku dan ruang produksi, dan (4) membuat papan informasi yang memuat informasi mengenai karyawan yang bertugas dalam pengawasan mesin. 


\section{Saran}

Saran yang direkomendasikan adalah:

1) Pemberian pelatihan GMP dan food safety dilakukan sebulan sekali. Pelatihan tidak harus bersifat formal sehingga karyawan dapat merasa nyaman terhadap pelatihan yang diberikan. Briefing harian dilakukan setiap hari dengan komunikasi dua arah di mana pimpinan briefing memberi arahan dan masukan kepada karyawan dan karyawan dipersilahkan untuk menyampaikan pendapat sehingga karyawan terlibat dalam keputusan yang dapat mempengaruhi pekerjaan mereka.

2) Hadiah yang diberikan kepada karyawan teladan sekiranya dalam bentuk yang dibutuhkan karyawan sehingga termotivasi untuk bekerja dengan baik. Hadiah dapat diberikan berupa tambahan gaji. Perusahaan juga dapat merundingkan hadiah seperti apa yang diinginkan karyawan dengan memberikan beberapa opsi hadiah yang dapat didiskusikan dalam suatu forum.

3) Departemen Personalia harus memaparkan apa saja kriteria dan sistem penilain agar karyawan dapat menerima penilaian yang diberikan.

\section{DAFTAR PUSTAKA}

Daulay, S. S. (2000). HAZARD ANALYSIS CRITICAL CONTROL POINT (HACCP) DAN IMPLEMENTASINYA DALAM INDUSTRI PANGAN. In Pusdiklat Industri. Retrieved from http://www.kemenperin.go.id/downl oad/6761/HACCP-dan-

Implementasinya-Dalam-IndustriPangan
Kotler, P. (2005). Total Quality Management. Jakarta: PT. Gramedia Pustaka.

Kotler, P., \& Armstrong, G. (2003). Dasar-Dasar Pemasaran. Jakarta: PT. Indeks Gramedia.

Lubis, M. (2016). Ketika Lebih Sedikit Lebih Baik. Retrieved August 30, 2019, from https://www.nielsen.com/

Mustofa, H. M. (2014). Perencaan Produktivitas Kerja dari Hasil Evaluasi Produktivitas dengan Metode Fishbone di Perusahaan Percetakaan Kemasan PT.X. Jurnal Teknik Industri HEURISTIC, Volume 11(1), 27-46.

Purnomo, B. H., Rusdianto, A. S., \& Hamdani, M. (2012). Desain Tata Letak Fasilitas Produksi pada Pengolahan Ribbed Smoked Sheet (RSS) Di Gunung Pasang Panti Kabupaten Jember.

Rini, F. A., Katili, P. B., \& Ummi, N. (2015). Penerapan Good Manufacturing Practices untuk Pemenuhan Manajemen Mutu pada Produksi Air Minum Dalam Kemasan (Studi Kasus di PT. XYZ). Jurnal Teknik Industri Untirta, 1-6.

Roestyah. (2008). Strategi Belajar Mengajar. Jakarta: Rineka Cipta.

Rudiyanto, H. (2016). Kajian Good Manufacturing Practices (Gmp) Dan Kualitas Mutu Pada Wingko Berdasarkan Sni-01-4311-1996. Jurnal Kesehatan Lingkungan, 8(2), $148-157$.

Sugiyono. (2018). Metode Penelitian Kuantitati, Kualitatif, dan R\&D. Bandung: Alfabeta.

Tohardi, A. (2002). Pemahaman Praktis Manajemen Sumber Daya Manusia. Bandung: Mandar Maju.

Triesty, A., \& Ririh, Y. (2011). Penerapan Good Manufactoring Practices Pada Industri Rumah Tangga Kerupuk 
Teripang di Sukolilo Surabaya. Jurnal Kesehatan Lingkungan, 7(2), 148-158.

Wardhanu, A. P., \& Anhar, M. (2016). Penerapan Good Manufacturing Practice (GMP) Pada Kelompok Usaha Bersama (KUB) Wida Mantolo Kecamatan Benua Kayong. Jurnal Teknologi Pangan, 7(1), 816. 